\title{
IMPLEMENTASI PEMBERDAYAAN USAHA EKONOMI MIKRO KECIL DAN MENENGAH (UMKM)
}

\author{
Goso $^{1}$, Samsul Bachri ${ }^{2}$ \\ ${ }^{1}$ Dosen Sekolah Tinggi Ilmu Ekonomi Muhammadiyah Palopo \\ ${ }^{2}$ Dosen Sekolah Tinggi Ilmu Ekonomi Muhammadiyah Palopo
}

\begin{abstract}
To speed up economy restoration with brace development basement sustainability and with justice based on in democracy economy system. Done to pass development at economy area with development at Natural Resources (SDA) and environment. Make use wealth SDA without neglecting principles sustainability and environment preservation. Effort development micro intermediate little can give big contribution towards bational economy restoration process so that necessary more be payed because, by using technics analysis diskriptif, technics factor analysis, and doubled linear regression is found factors that determine development success UMKM among others Human Resource (SDM), capitalization, engine and device, effort management, marketing, basic commodity availability, and information so that can do global access. Bear mission creats generalization chances work and try to preserve culture, and support to export national. Technicaly survey existence UMKM at unlucky city to effort areas classification arrangement, effort stratification, and troubleshoot identification, need, and the potential, with influential factors towards the development. Furthermore evaluation towards that got and database that made based on the effort area classification operationally permanent refer in construction masterplan and small industry development and intermediate with pay attention potential region.
\end{abstract}

Keyword: UMKM; Enableness; Development; Implementation; Effort Opportunity

\section{PENDAHULUAN}

Lambatnya proses pemulihan ekonomi Indonesia setelah krisis tahun 1998 masih terasa dan menyisakan dampak baik sosial maupun ekonomi hingga kini hal ini terutama disebabkan oleh dua faktor utama. Pertama, penyelenggaraan negara di bidang ekonomi yang selama ini dilakukan atas dasar kekuasaan yang terpusat dengan campur tangan pemerintah yang terlalu besar sehingga mengakibatkan kedaulatan ekonomi tidak berada di tangan rakyat dan mekanisme pasar tidak berfungsi secara efektif. Kedua, kesenjangan ekonomi yang meliputi kesenjangan antara pusat dan daerah, antardaerah, antarpelaku, dan antargolongan pendapatan, telah meluas ke seluruh aspek kehidupan sehingga struktur ekonomi tidak mampu menopangnya. Ini ditandai dengan masih berkembangnya monopoli serta pemusatan kekuatan ekonomi di tangan sekelompok kecil masyarakat dan daerah tertentu.
Adapun sasaran pembangunan di bidang ekonomi adalah mempercepat proses pemulihan ekonomi, antara lain ditunjukkan oleh pertumbuhan ekonomi Indonesia periode 20092013 mencapai rata-rata 5,9 persen, namun laju inflasi masih sekitar $8-9$ persen, menurunnya tingkat pengangguran terbuka dari 9,86 persen pada tahun 2004 menjadi sekitar 5,92 persen pada bulan maret 2013 dan menurunnya jumlah angka kemiskinan (penduduk miskin) dari 37,2 juta jiwa menjadi sekitar28,07 juta orang pada maret 2013. Sasaran selanjutnya adalah makin kukuhnya ketahanan ekonomi nasional yang ditunjukkan oleh meningkatnya daya saing dan efisiensi perekonomian, terciptanya struktur perekonomian yang kuat berlandaskan keunggulan kompetitif, serta meningkatnya dan lebih meratanya ketersediaan sarana dan prasarana pembangunan. Usaha Mikro, Kecil dan Menengah (UMKM) 
merupakan salah satu bagian penting dari perekonomian suatu Negara ataupun daerah, tidak terkecuali di Indonesia. Sebagai gambaran, kendati sumbangannya dalam output nasional (PDRB) hanya 56,7 persen dan dalam ekspor nonmigas hanya 15 persen, namun UMKM memberi kontribusi sekitar 99 persen dalam jumlah badan usaha di Indonesia serta mempunyai andil 99,6 persen dalam penyerapan tenaga kerja.

Pengembangan Usaha Kecil dan Menengah diharapkan dapat memberikan kontribusi yang besar terhadap Proses Pemulihan Perekonomian Nasional sehingga perlu lebih diperhatikan karena mengemban misi menciptakan pemerataan kesempatan kerja dan berusaha, melestarikan budaya, dan mendukung ekspor nasional.

Terdapat dua prioritas dalam pengembangan Usaha Skala Kecil dan Menengah (UKM) sebagai tulang punggung Ekonomi Kerakyatan dan memperluas partisipasi masyarakat dalam pembangunan yaitu Prioritas Jangka Pendek diberikan untuk mempercepat peningkatan skala Usaha Kecil, dan Menengah serta meningkatkan aksesnya pada permodalan, Prioritas Jangka Menengah diarahkan untuk meningkatkan akses Usaha Kecil, dan Menengah pada sumber daya produktif dan mengembangkan kewirausahaan. Penelitian ini bertujuan untuk mengidentifikasi dan evaluasi permasalahan, kebutuhan, dan potensi Usaha Kecil dan Menengah di Kota Palopo

\section{BAHAN DAN METODE}

Kebijakan Negara yang sentralistik beberapa waktu yang lalu, masih terasakan dampaknya. Lebih khusus dalam kebijakan ekonomi yang sentralistik dan orientasi pembangunan yang menekan pada aspek pertumbuhan, dimana usaha besar dijadikan sebagai roda penggerak ekonomi Nasional, ternyata tidak terbukti memberikan nilai lebih, bahkan tidak mampu bertahan saat krisis melanda Indonesia dan Asia pada umumnya. Kesalahan kebijakan investasi dan "kebocoran" di berbagai sektor pemerintahan telah mengakibatkan dunia usaha terpuruk dan selanjutnya menyeret keterpurukan pada sektor ekonomi yang lain.

Dalam kondisi diatas, maka usaha kecil terbukti mampu menjadi "penyangga" perekonomian rakyat, karena keadaan tersebut mendorong inisiatif masyarakat khususnya perempuan untuk melakukan kegiatan ekonomi pinggiran sebagai upaya bertahan hidup. Hal ini nampak pada pertumbuhan secara kuantitatif jumlah pelaku usaha kecil di Indonesia tahun 2001 yang mencapai 40.137 .773 juta $(99,86 \%)$ dari total jumlah pelaku usaha 40.197.61 juta, sementara pelaku usaha mikro mencapai $97,6 \%$ dari jumlah pelaku usaha kecil (BPS 2001). Jumlah tersebut menunjukkan kontribusi sangat besar UK terhadap pertumbuhan ekonomi. Menurut perhitungan BPS dengan jumlah tersebut UK mampu menyediakan 99,04\% lapangan kerja Nasional, sumbangan terhadap PDB mencapai 63,11\% dan memberikan pemasukan sebesar $14,20 \%$ diluar non migas. (BPS, 2001).

Nilai strategis lain usaha kecilmikro adalah kemampuannya menjadi sarana pemerataan kesejahteraan rakyat. Karena jumlah besar, biasanya bersifat padat karya sehingga mampu menyerap tenaga kerja yang besar, meskipun ukuran unitnya kecil tetapi jumlah banyak 
memungkinkan orang lebih banyak terlibat untuk menarik manfaat didalamnya. Lebih lanjut, pada tahun sebelumnya (BPS, 2000) di katakan bahwa dari jumlah 2.002.335 unit usaha kecil, dan 194, 564 unit usaha mikro, di sektor pengolahan jumlah perempuan pelaku ada 896.047 (40,79\%), dan angka tersebut diyakini lebih besar lagi mengingat bahwa data tersebut dibuat berdasarkan kepemilikan formal, bukan pelaku (riil) usaha. Keyakinan ini berdasarkan pada realitas adanya hambatan mobilitas perempuan dalam usaha, bahkan beberapa pengalaman menunjukkan bahwa usaha yang semula dirintis oleh perempuan, setelah usaha tersebut berkembang pengelolaan dan kepemilikan formalnya bergeser pada lakilaki, karena membutuhkan mobilitas tinggi.

Dengan mencermati perihal data diatas, maka semakin jelas kontribusi Usaha kecilmikro khususnya perempuan dalam perekonomian keluarga dan Negara secara umum. Meskipun terbukti kontribusi usaha kecil-mikro. Perempuan yang sangat strategis, namun belum seimbang dengan perhatian dan pengakuan yang diberikan, baik oleh pemerintah, maupun keluarga. Bahkan usaha kecil-mikro-perempuan masih mengalami banyak permasalahan yang disebabkan ketidak adilan struktur maupun budaya. Jiwa

\section{Kewirausahaan}

Wirausahawan adalah individuindividu yang berorientasi kepada tindakan dan bermotivasi tinggi yang mengambil resiko dalam mengejar tujuannya. Menurut Lokakarya (1977), profil dari wirausahawan mempunyai ciriciri dan sifatsifat mental sebagai berikut: ciri-ciri yaitu percaya diri, berorientasi tugas dan hasil, pengambilan resiko, kepemimpinan, keorisinilan, berorientasi ke masa depan. Keberhasilan Perusahaan

Keberhasilan menunjukkan suatu tingkat kerja karena telah melahirkan suatu aktivitas atau usaha. Di dalam mengukur keberhasilan, mungkin masingmasing bidang memakai tolok ukur yang berbeda. Menurut pendapat Guiltinon dan G.W. Paul (1994) untuk mengukur keberhasilan dilihat dari analisis kemampulabaan (profitabilitas) yang dibedakan berdasarkan pada keputusan manajemen yang diperlukan.

\section{Faktor-faktor yang Mempengaruhi Strategi Pemasaran}

Di lungkungan pemasaran, setiap perusahaan harus memulai kembali secara periodik efektivitas pemasarannya melalui suatu alat pengendalian. perusahaan mengembangkan kombinasi variabel bauran pemasaran yang terdiri dari beberapa faktor yang berada di bawah pengendaliannya, yaitu produk, harga, tempat dan promosi. Untuk sampai pada kombinasi bauran pemasaran itu, perusahaan mengelola empat sistem: sistem informasi pemasaran, sistem perencanaan pemasaran, sistem organisasi pemasaran dan sistem pengedalian pemasaran. Sistemsistem tersebut berkaitan satu sama lain, sehingga informasi pemasaran, yang selanjutnya dilaksanakan oleh organisasi pemasaran dan hasil pelaksanaannya itu ditinjau kembali dan dikendalikan.

\section{Loyalitas Melalui Customer Relationship}

Perubahan mendasar perkembangan ilmu pemasaran adalah perubahan dari transaksional menjadi pemasaran berbasis hubungan (relationship-based marketing). 


\section{Citra Perusahaan}

Usaha pembentukan citra dan sikap perusahaan yang positif akan sangat membantu usaha perusahaan dalam kegiatan pemasarannya, karena dalam kondisi bagaimanapun suatu Pemasaran tidak lagi dilihat sebagai satu fungsi manajemen yang terpisah. Setiap orang dalam perusahaan tersebut bertanggung jawab mengelola pelanggan. Artinya, setiap orang bertanggung jawab untuk memuaskan pelanggan.

Menciptakan nilai buat pelanggan berkaitan erat dengan 4P, yaitu: Product, Process, Performance, dan people. Produk atau jasa yang menjadi inti usaha merupakan esensi yang harus disediakan oleh perusahaan dengan kualitas yang tinggi. Sedangkan process merupakan cara untuk menjaga agar sistem terus bekerja secara lancar.
Performance merupakan janji kita kepada pelanggan yang harus ditepati. Dalam hal ini, ketidakpuasan yang muncul bukan diakibatkan oleh core product yang tidak superior, tetapi oleh ketidakmampuan perusahaan untuk menyediakan kinerja sesuai dengan yang dijanjikan. Terakhir adalah people, yaitu bagaimana pelanggan memandang karyawan kita sebagai orang yang dapat melayani, kompeten, penuh pengertian, dan sopan.

perusahaan akan selalu berusaha menempatkan dirinya sebaik mungkin di mata pelanggan. Perusahaan perlu menciptakan citra yang positif untuk mempengaruhi sikap dan citra pelanggan yang positif terhadap perusahaan. Citra terhadap perusahaan mempunyai beberapa makna, ada perusahaan yang dinilai baik, biasa saja, dan ada yang dinilai kurang bahkan tidak baik.

\section{Gambar: 1 Transaction-Relationship Continuum}

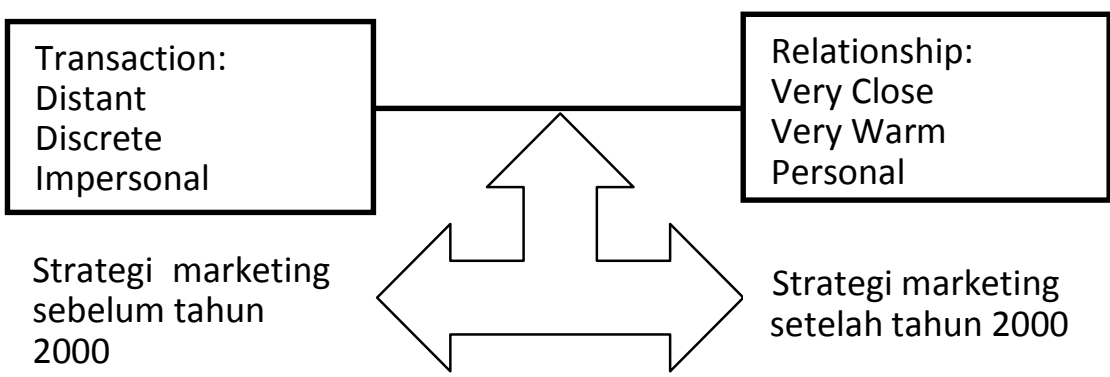

Sumber: James G. Barnes (1994:561) 


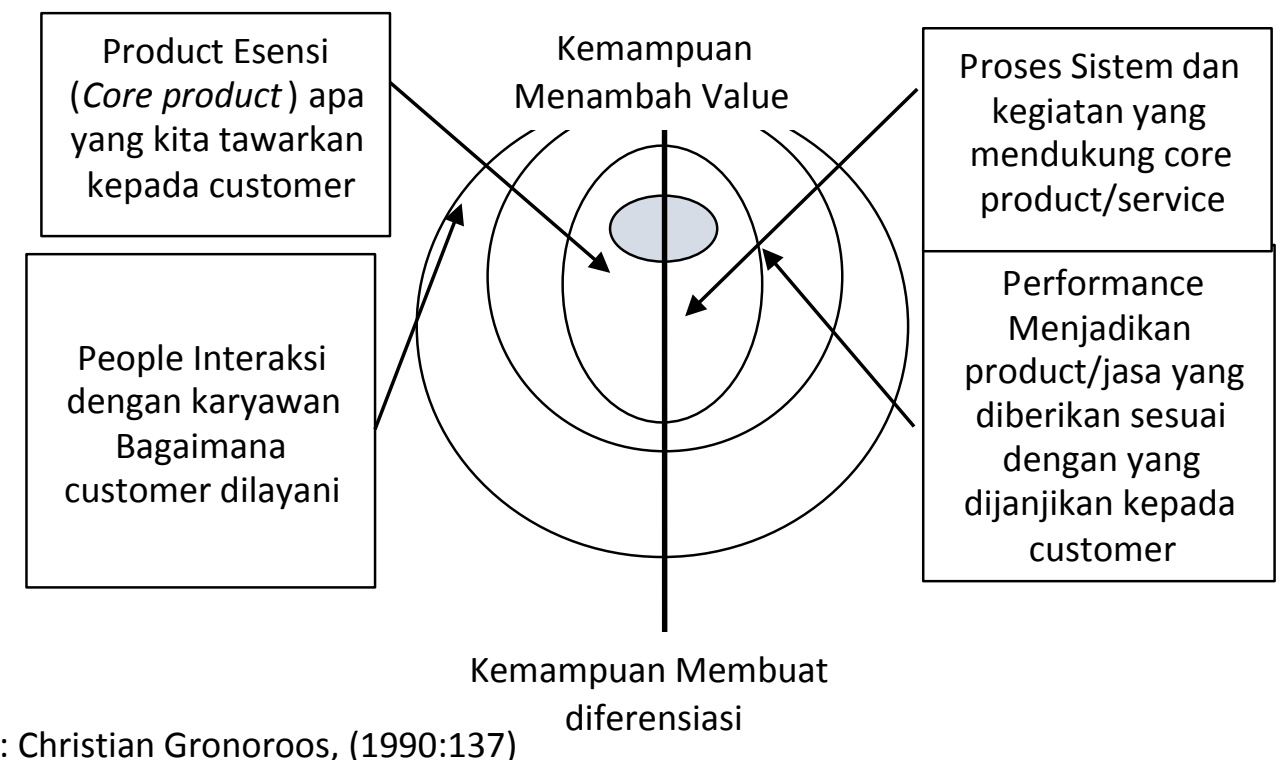

Sumber: Christian Gronoroos, (1990:137)

\section{Metodologi}

Jenis penelitian ini adalah deskriptif-evaluatif, yaitu sebuah penelitian menggambarkan fenomena dan berbagai persoalan yang ada. Penelitian ini mengamati dan menganalisis fenomena dengan menggunakan metode before - after yaitu; menganalisis penggunaan pedoman yang dijadikan landasan oleh Pemerintah Kota Palopo dalam berbagai kebijakan pemberdayaan UMKM. Lokasi penelitian ini di Kota Palopo dan studi sampling ditetapkan secara purposive, yaitu usaha/industri kecil di daerah selain mempunyai karakteristik produk sejenis dan juga iklim daerah yang tidak jauh berbeda stratifikasi usaha. Jenis data penelitian yang dikumpulkan adalah data primer yang diperoleh melalui observasi atau interview, dan data sekunder yaitu data yang diperoleh dari laporan-laporan, meliputi: RPJM, Disperindagkop, Partisipasi Angkatan Kerja, laporan masingmasing dinas terkait tentang UMKM. Data penelitian dilakukan melalui studi kasus dan studi komparatif melalui telaah kajian sebelumnya dan referensi kebijakan, agar diperoleh data yang cukup dan dapat dipertanggungjawabkan. Studi kasus dilakukan pada obyek sasaran UMKM sesuai kriteria yang sudah ditetapkan.

Hasil dari penelitian dianalisis dengan metode survey dan kunjungan (partisipatoris) ke sejumlah lokasi UMKM di Wilayah Kota Palopo dan terkait kebijakan instansi terkait yang dijadikan obyek penelitian ini: (1) Analisis potensi, permasalahan dan pengembangan meliputi kegiatan: (i) Identifikasi potensi dan permasalahan (mapping) per sektor usaha serta nilai produksi; (ii) Identifikasi potensi, permasalahan dan pengembangan komoditi produk unggulan per jenis komoditi per sektor nilai produksi. (2) Analisis terhadap sumberdaya UMKM yang dimiliki saat ini meliputi kegiatan: (i) Identifikasi sumberdaya: SDM, tangible, dan intangible; (ii) Identifikasi kapabilitas sumberdaya UMKM (3) Analisis terhadap manajemen. (4) Analisis kebijakan. 


\section{HASIL}

Hasil survey tentang UKM, menunjukkan fenomena dari aspek umum pada UKM di Kota Palopo, terlihat memiliki beberapa karakteristik yaitu antara lain bahwa sebagian besar UKM di Kota Palopo mempunyai kelemahan dalam bidang kelembagaan dimana umumnya masih bersifat home industry yang tidak jelas struktur organisasinya, pembagian tugasnya, serta wewenangnya. Kesemrawutan seperti inilah yang sering menjadi pangkal ketidakberhasilan perusahaan kecil (UKM). Dan jika ini dibiarkan berlarutlarut akan dapat berakibat lebih parah. UKM, sebaiknya sejak awal sudah mengenal dan menerapkan prinsip keorganisasian, karena pada dasarnya, setiap organisasi betapapun kecilnya, termasuk UKM, harus menjalankan prinsip-prinsip keorganisasian.

Pengolahan data terhadap 28 jenis usaha UKM yang ada di kota palopo, akhirnya didapatkan jenis-jenis usaha yang menentukan pertumbuhan ekonomi kota palopo berdasarkan jumlah UKM, jumlah tenaga kerja, nilai asset dan nilai omset, yaitu antara lain usaha bengkel las dan logam, konveksi, roti, mebel dan percetakan. kelima jenis usaha ini, ternyata mendominasi baik dari jumlah UKM, jumlah tenaga kerja, nilai asset dan nilai omset. Berdasarkan jumlah tiap-tiap UKM, jenis usaha yang berpengaruh terhadap pertumbuhan ekonomi di kota palopo adalah las logam, konveksi, mebel, percetakan dan roti, kelima jenis usaha ini ternyata mendominasi jumlah UKM yang ada, yaitu 54.36 \% atau sebanyak 586 dari total jumlah UKM di kota palopo yaitu sebanyak 1,078. sedangkan berdasarkan jumlah tenaga kerja, jenis usaha konveksi, logam, mebel, roti dan percetakan, mendominasi jumlah tenaga kerja yang ada di kota palopo, yaitu $67.49 \%$ atau 8064 orang dari total jumlah tenaga kerja sebesar 11,948 orang. Dari nilai asset, jenis usaha roti, percetakan, konveksi, logam dan mebel, ternyata sangat mendominasi nilai asset yang ada, yaitu $82.83 \%$ atau sebesar 122,018,118.000 (seratus dua puluh dua milyar delapan belas juta seratus delapan belas ribu rupiah) dari total jumlah nilai asset yaitu sebesar 148.202.207.000 (seratus empat puluh delapan milyar dua ratus dua juta dua ratus tujuh ribu rupiah) dan untuk nilai omset, jenis usaha logam, konveksi, roti, mebel dan percetakan, ternyata juga mendominasi nilai omset yang ada, yaitu $69.32 \%$ atau sebesar 27,736,000.000 (dua puluh tujuh milyar tujuh ratus tiga puluh enam juta rupiah) dari total jumlah nilai omset ukm di kota palopo sebesar 40.014.000.000 (empat puluh milyar empat belas juta rupiah).

\section{PEMBAHASAN}

Keberhasilan dalam pertumbuhan ekonomi saja belum mampu mencerminkan peningkatan dalam kesejahteraan bagi masyarakat, meskipun jika dilihat dari perkembangan pendapatan perkapita masyarakat Kota Palopo juga terjadi peningkatan nilai secara nominal, namun ini belum cukup untuk memperlihatkan keberhasilan pembangunan kota. Indikator penting lainnya yang harus diperhatikan adalah apakah peningkatan pertumbuhan ekonomi juga diikuti oleh kemampuan daya serap terhadap tenaga kerja sehingga semakin banyak masyarakat yang 
berpartisipasi dalam aktivitas ekonomi, baik di lapangan kerja formal maupun informal, yang pada akhirnya akan semakin menurunkan tingkat pengangguran dan kemiskinan di kota ini. Program-program pengembangan UKM hanya merupakan rumusan tertulis yang kurang disertai dengan komitmen yang terus-menerus untuk mengangkat derajat UKM. Bisa jadi hal ini terjadi karena pemerintah dihadapkan kepada permasalahan anggaran pembinaan yang terbatas pada instansi terkait serta kurangnya koordinasi antar pelaksana kebijakan yang saling berhubungan. Dan hal ini akhirnya menuntut Usaha Kecil Menengah untuk bisa memberdayakan diri dan memompa kreatifitasnya, sehingga diharapkan Usaha Kecil Menengah yang dirintis menjadi tangguh, mandiri dan juga dapat berkembang menjadi Usaha Besar dan sejajar dengan pengusaha-pengusaha lainnya.

Dari aspek tenaga kerja, diperlukan usaha keras pemerintah untuk terus mendorong keberadaan usaha UKM seperti mengembangkan industri-industri kecil baru/meningkatkan sentrasentra industri agar tenaga kerja yang terserap di sektor UKM lebih banyak lagi. Dan hal ini secara tidak langsung akan mengurangi jumlah pengangguran yang semakin hari semakin banyak.

Dari aspek modal, sebagian besar UKM di Kota Palopo dalam permasalahan modal sebenarnya bukan masalah utama bagi pengelola UKM, dan mereka sudah tidak terlalu bergantung pada pemberi modal seperti bank atau koperasi, karena umumnya modal usaha adalah dari mereka sendiri. Tetapi walau demikian, secara umum pada hakekatnya mereka juga tidak menolak tambahan modal terutama apabila ada bantuan-bantuan kredit yang bersifat lunak.

Kondisi aspek produksi juga harus menjadi perhatian, karena memberikan dampak yang cukup besar dalam proses produksi. Aspek produksi pada UKM di Kota Palopo meliputi volume produksi dan biaya produksi. Volume produksi UKM di Kota Palopo, sebagian besar masih tergantung pada pesanan. Tentu saja hal ini sangat besar pengaruhnya pada kemajuan usaha tersebut. Suatu usaha yang berproduksi dengan hanya mengandalkan pesanan, maka usaha tersebut tidak akan mampu berkembang dan bersaing dibandingkan dengan usaha lain. Sedangkan biaya produksi yang dibutuhkan dalam suatu produksi tergantung pada besarnya volume produksi dan besarnya pun tidak tetap tergantung pada banyak sedikitnya pesanan, bila pesanan banyak maka biaya produksi pun juga akan bertambah. Disamping kedua hal tersebut di atas, terdapat juga aspek teknologi dan bahan baku, aspek produksi pada UKM di Kota Palopo, terlihat memiliki kelemahan yaitu bahwa teknologi yang dipakai dalam proses produksi umumnya masih bersifat tradisional walaupun juga sudah cukup banyak yang menggunakan teknologi semi modern. Kalau hal ini tetap dibiarkan akan mempengaruhi terhadap perkembangan UKM tersebut untuk bersaing dengan industri yang lain yang sudah menggunakan teknologi modern. Keterbelakangan teknologi ini bukan hanya membuat rendahnya seluruh faktor produksi dan efisiensi dalam proses produksi, tetapi juga rendahnya kualitas produk yang dibuat. Sedangkan dalam aspek bahan baku, UKM di Kota Palopo tidak terlalu kerepotan untuk memperolehnya karena sebagian besar bahan baku 
sudah tersedia di Palopo dan sekitarnya. Namun juga tidak dapat dipungkiri bahwa di beberapa sentra UKM banyak yang mengalami kesulitan mendapatkan bahan baku atau input lainnya (walaupun di sekitar Palopo banyak tersedia) yang disebabkan karena harganya yang mahal akibat depresiasi nilai tukar rupiah terhadap dollar.

Aspek Pemasaran pada UKM di Kota Palopo dapat disederhanakan dalam tabel di bawah ini. Pada umumnya UKM memiliki lingkup daerah pemasaran yang sempit, yaitu daerah pemasaran dalam dan luar kota, sedangkan daerah pemasaran ekspor belum menjadi sasaran utamanya, padahal bila jeli dalam menangkap peluang pasar, maka UKM bisa menjadikan perbedaan komoditi dalam suatu daerah/negara untuk memasukkan komoditinya ke daerah/negara yang membutuhkan, sehingga terjadi hubungan timbal balik satu sama lain, yang pastinya akan mendatangkan profit bagi UKM itu sendiri dan devisa bagi Negara. Maka dalam hal ini tugas pemerintahlah yang harus memberikan bantuan informasi tentang peluang pasar terutama peluang ekspor, dan ini juga terkait dengan rencana pasar yang dibidik. Pada umumnya UKM di Kota Palopo hanya membidik lingkup daerah pemasaran yang sempit, yaitu daerah pemasaran lokal sedangkan daerah pemasaran luar kota dan ekspor belum menjadi sasaran utamanya.

Pertumbuhan penyerapan tenaga kerja sektor industri rata-rata hanya sebesar $0,85 \%$ pertahun. Lambatnya penyerapan tenaga kerja sektor industri disebabkan oleh banyaknya kendala yang dimiliki oleh pengusaha skala kecil dan mikro dalam hal sebagai berikut :
Kendala Internal, yang meliputi: (i) Kendala dalam memperoleh informasi pasar; (ii)Keterbatasan dalam pemanfaatan dan penguasaan teknologi; (iii) Keterbatasan jaringan usaha dan kerjasama usaha; (iv) Kelemahan di bidang organisasi dan manajemen. (v) Kelemahan dalam struktur permodalan.

Kendala eksternal, diantaranya adalah: (i) Iklim persaingan yang belum sehat. (ii) Sarana dan prasarana pendukung yang kurang memadai; (iii) Pembinaan yang masih kurang terpadu; (iv) Image bahwa IKM kurang menguntungkan Investor.

Keadaan yang diperlukan agar pemberdayaan UKM dapat dilaksanakan yaitu: (i) Lingkungan yang kompetitif; (ii) Akses pendanaan; (iii) Kompetensi teknis dan pengusahaan; (iv) Dasar hukum dan kepastian hukum.

Menerapkan langkah-langkah pendekatan secara komprehensif integral yang dilakukan dengan melalui pembinaan berbagai aspek antara lain akses pasar, permodalan, teknologi dan manajemen secara menyeluruh mulai dari proses produksi hingga pemasaran dan dilakukan secara terpadu antar instansi. Tujuan pembinaan UKM tersebut adalah: (i) Meningkatkan akses pasar dan memperbesar pangsa pasar; (ii) Meningkatkan akses terhadap sumbersumber modal dan memperkuat struktur modal; (iii) Meningkatkan kemampuan organisasi dan manajemen; (iv) Meningkatkan akses dan penguasaan teknologi.

Melakukan penataan dan pemantapan kelembagaan baik secara vertikal maupun horisontal. Penataan kelembagaan penunjangnya akan mempermudah pembentukan jaringan usaha 
dan distribusi sehingga akan tercapai efisiensi. Disamping itu dunia usaha harus terus menerus melakukan langkah-langkah untuk meningkatkan penguasaan teknologi, produktivitas, kualitas dan pengelolaan manajemen secara profesional.

Melakukan penelitian dan pengembangan (Litbang) tentang perkembangan UKM. Peningkatan daya saing harus didukung oleh kegiatan penelitian dan pengembangan yang mendukung. Kecenderungan yang harus diperhitungkan adalah kemajuan teknologi dan teknik pemasaran. Oleh karena itu, Pemerintah dan para pengusaha perlu mengamati dan mulai menerapkan teknologi tepat guna untuk menghasilkan produk-produk bermutu tinggi melalui perhitungan kemampuan litbang terapan, sehingga dapat diharapkan dengan litbang terapan ini dapat diperoleh mutu produk yang tinggi dan menghasilkan diversifikasi produk dalam rangka pemasaran.

Untuk menciptakan produk yang berdaya saing tinggi, maka salah satu strategi yang dilaksanakan antara lain melalui pemanfaatan keunggulan komparatif yang dimiliki karena tersedianya sumber daya alam dan menciptakan keunggulan kompetitif melalui pengembangan sumber daya manusia yang semakin terampil dan peningkatan kemampuan penguasaan teknologi. Sumber daya alam yang yang terbatas dan alternatif pemanfaatannya diarahkan kepada produk-produk yang memberikan kontribusi besar terhadap peningkatan nilai tambah. Untuk meningkatkan keunggulan kompetitif, pengusaha harus didorong untuk terus berusaha memperkuat kemampuannya karena rata-rata pengusaha UKM di Kota Palopo tidak mempunyai competition drive untuk bersaing di pasaran

\section{KESIMPULAN}

Aspek promosi, sebagian besar UKM di Kota Palopo tidak melakukan promosi. Kebanyakan UKM enggan melakukan promosi ala perusahaan besar. Akibatnya, hasil usahanya kurang dikenal masyarakat luas sehingga kurang berkembang. Sementara itu, para pesaing makin getol berpromosi dengan terarah dan intensif. Akibatnya omset penjualan makin menurun, merugi dan salah-salah dapat gulung tikar karena kalah bersaing. Dalam persaingan yang kian keras ini, promosi nampaknya sudah menjadi keharusan. Promosi merupakan suatu kegiatan untuk memperkenalkan kebaikan, manfaat, harga yang murah dan sebagainya kepada calon konsumen. Promosi secara tidak langsung membujuk dan merangsang calon konsumen untuk mengenal, berminat dan akhirnya sampai pada keputusan untuk membeli.

Sedangkan mengenai jaringan distribusi pada UKM di Kota Palopo, pada umumnya mereka tidak memiliki. Padahal agar produk sampai kepada konsumen dengan cepat, jaringan distribusi ini sangat diperlukan.

\section{DAFTAR PUSTAKA}

Anderson, Tommy. D. 1987. Profit in Small Firms, School of Economics University of Gothenberg, Sweden.

Buku Petunjuk Teknis Pengembangan Sentra Industri Kecil yang Tangguh dan Potensial. 2010. Deperindag Propinsi Sulawesi Selatan. 
Christian, Gronoroos. 1990. Service Management and Marketing,

Lexington, Mass Lexington Engel, J.F. dan Roger D. Blackwell. 1995. Perilaku Konsumen. Buku Dua, Edisi Keenam, Binarupa Aksara, Jakarta.

Fornell Claes, et al., 1995. Business Research Methods, Fith edition, USA: Richad D. Irwin, Inc.

Gay, L.R. Diehl, P.L. 1992. Research Methods for Business and Management, Mac Milan Publishing Company, USA.

Kusdyah R, Ike. 2003. Pemberdayaan Usaha Kecil dan Menengah Melalui ProgramKemitraan. Jurnal Ekonomi Pembangunan. Vol. 01, No. 2, Desember.

Kota Palopo Dalam Angka, Tahun, 2012. 2013. BPS. Kota Palopo.

Propenas 2000 - 2004, Undang-undang No. 25 Tahun. 2000 tentang ProgramPembangunan Nasional Tahun 2000 - 2004. 2003. Cetakan II. Penerbit Sinar Grafika. Jakarta.

Rencana Strategis Kota Palopo Tahun 2009 2013. 2010. Pemerintah Kota Palopo.

Sarbini Sumawinata, 2004, Politik Ekonomi Kerakyatan, Cetakan I, Penerbit PT. Gramedia Pustaka Utama.

Sevilla, G. Consuelo dan Punsalau T.G Rigala. 1993. Pengantar Metode Penelitian (Alih Bahasa Alimuddin Tuwu) Cetakan I. Jakarta, Penerbit UI.

Singarimbun, I dan S. Effendi. 1987. Metode Penelitian Survey, Jakarta, Lembaga Penelitian, Pendidikan dan Penerapan Ekonomi dan Sosial.

Thee Kian Wee, dkk. 1999. Undangundang Anti Monopoli Indonesia dan Dampaknya terhadap Usaha Kecil dan Menengah, The Indonesian Foundation, Jakarta.
Tiktik Sartika Partono, Abd. Rahman Soedjono. 2002. Ekonomi Skala Kecil /Menengah dan Koperasi, Cetakan I, Penerbit Ghalia Indonesia.

Undang-undang RI No. 9 Th. 1995. 1995. Tentang Kriteria Usaha Kecil. Pemerintah RI. Jakarta.

Undang-undang RI No. 25 Th. 1992. 1992. Tentang Perkoperasian, Jakarta.

Wibowo. Singgih, Murdinah, Nuri Fawza. Yusro. 2002. Pedoman MengelolaPerusahaan Kecil. Penerbit Swadaya. Jakarta. 